Psychology of Language and Communication 2008, Vol. 12, No. 2

DOI: $10.2478 / \mathrm{v} 10057-008-0008-8$

\author{
EWA MUZYKA \\ Maria Curie-Skłodowska University, Lublin
}

\title{
ACQUISITION OF WORD-FORMATION CATEGORIES BY CHILDREN WITH HEARING LOSS
}

\begin{abstract}
The article describes the competence of children with hearing loss in comprehending and producing derivational (word-formation constructions) belonging to various categories. The skills of children with hearing loss are compared with the skills of hearing children. The extensive field of observation - the object of study were all word-formation categories (productive in contemporary Polish) - caused this article to focus exclusively on quantitative analyses. The conclusions that follow from them allow us to determine the hierarchy of word-formation categories, ordered according to the degree of difficulty, and to compare the level of their acquisition by hearing children, hard-of-hearing children (using the hearing sense) and by deaf ones (not using the hearing sense). This hierarchy is different in the area of interpreting than in the area of producing derivational (word-formation) constructions. The degree of complication of the semantic structure of the categories investigated has a distinct effect on the level of their acquisition. If we adopt the view that the categorization of the world by the learning mind is reflected in derivational constructions, analyses of the abilities of children with hearing loss in this sphere of linguistic functions allow us to access the available subjective ways of how they perceive and interpret the phenomena of treality. The analyses proper are preceded by a description of the investigation instrument employed: a word-formation questionnaire, which is a methodological proposal for studying word formation in school-age children.
\end{abstract}

Key words: hearing impairment, word-formation constructions, school-age children, derivation, modification categories, mutation categories.

\section{Introduction}

Hearing impairments produce difficulties in language acquisition. The effect of hearing impairment can be exclusively speech impediments, while the effect of deafness are serious delays in the acquisition of the lexicon and grammatical rules, and, in extreme cases, even the arrest of language development. The degree of hearing loss alone merely suggests the rise of some kind of problems with language acquisition but it does not indicate the real possibilities of the child's language development. The latter depends not only on the degree of hearing loss but also on

Address for correspondence: Ewa Muzyka, Maria Curie-Skłodowska University, Department of Logopedics and Applied Linguistics, Lublin. E-mail: ewamuzyka@wp.pl 
a number of other factors that, when in specific configurations, speed up or slow down the process of language acquisition. The factors that directly influence the child with hearing loss include: the degree and type of hearing loss, causes and time of impairment, the time of detection of a hearing defect and provision of a hearing aid, the right choice and advantages of hearing aids or cochlear implants, the start of early and comprehensive care, involvement of parents in rehabilitation, the environment the child lives in (the environment of hearing persons or those with hearing loss, speaking or using sign language), the occurrence of impairments combined with the hearing defect, the child's intellectual capability, etc.

The diversity of factors that influence the development of every child with hearing loss is the direct cause of lack of homogeneity of the population of persons with hearing loss regarding language skills attained. They are basically joined only by the cause of difficulties in language acquisition, i.e., the hearing impairment. Consequently, it is impossible to select a group of children with hearing loss, whose linguistic development would be determined by the same factors. This is one of the fundamental methodological problems that arise in present studies on persons with hearing loss. Almost any of the aforementioned factors can be a variable to be taken into account in investigations and can thereby influence the form of adopted research hypotheses, research objectives, and the selection of groups to be studied.

Another problem is connected with the choice of object of investigation. Much has already been written about difficulties in language acquisition by children with various hearing impairments, but very little about difficulties in word formation (apart from fragmentary descriptions of the ability to produce diminutives - Rakowska, 1992; Krakowiak, 1995). Despite the fact that word-formation processes in Polish are extremely varied, productive, and are the principal way of widening the lexicon, there are no studies that have dealt with the skills of children with hearing loss in the comprehension and formation of words with a complex derivational (morphological) structure. Because of the special role of word-formation processes in learning language, and therefore, in structuring the phenomena in surrounding reality (Rozwadowski, 1921; Dokulil, 1979; Grabias, 1994; Waszakowa, 1996; Grzegorczykowa \& Szymanek, 2001) the lack of studies in this area seems to be an oversight.

\section{Word formation in Polish}

Language constructs the image of the world in human minds, and as a system of social categories, it uniformizes cognition (Grabias, 2007, p. 376). The relation between cognitive and linguistic processes can be seen on different language levels, including word formation (inter alia Rozwadowski, 1921; Dokulil, 1979; Grabias, 1994; Grzegorczykowa \& Szymanek, 2001; Waszakowa, 1996). Derivational morphemes refer us to intersubjective or social intellectual categories, by means of which we interpret reality (Grabias, 1994, p. 197). In derivationally divisible words, the manner of human perception of the phenomena of reality is manifested. Derivation- 
ally divisible words thereby reflect the categorization of the world characteristic of a given language (Waszakowa, 1996, Grzegorczykowa \& Szymanek, 2001).

This idea developed from the early twentieth century. It had already appeared in the studies by Henryk Ułaszyn (1915), and was fully developed in the now classical conceptions of Jan Rozwadowski (1921) and Miloš Dokulil (1979).

Rozwadowski, in developing Ułaszyn's ideas, showed that a derivational construction reflects a dual perception of the world: in learning the phenomena of reality, man perceives them first as a whole or a set of features, on the basis of which $\mathrm{s} /$ he assigns new phenomena to the general class of prior concepts (products, agents, places, small or large creatures), and then s/he focuses on one element that distinguishes a given object from others similar to it. This cognitive process is reflected in the dual structure of a derivational construction, of which one element is the identifying (generalizing) component, and the other is the distinguishing (specifying) component. This means that one component of a derivational construction expresses the dominant feature on the basis of which a particular construction is assigned to a class of generally known concepts (e.g. derivational morphemes: $-a c z$, -arz, -ak carry the meaning of 'one that performs a specific action', i.e., they refer to the category of personal or impersonal doers of action) while the other component expresses the differentiating feature that distinguishes a given object from other similar ones (e.g., ten, kto gra w pitke - pitkarz [one who plays ball - footballer]; ten, kto maluje - malarz [one who paints - painter] are the names of doers of different actions). Hence a derivational construction, like a definition, expresses a generic feature as genus proximum (here: doer of action) and a differentiating feature as differentia specifica, (here: doer of a specific action), which reflects a dual perception of the world. Construction is thus, in Rozwadowski's interpretation, a concise and compact definition.

Rozwadowski's theory was developed in the studies by Dokulil as the conception of onomasiological structures. Dokulil introduced the concept of onomasiological categories which are basic conceptual structures that form the base of a noun [name] in a given language (Dokulil, 1979, p. 41) and distinguished their types: modifications, mutations, and transpositions.

The essence of modification in word formation is the addition of a specific complementary sign (expanding and modifying) to the content of a concept (Dokulil 1979, pp. 66-67). A modification construction (e.g., piesek [doggie]) names the same object (phenomenon) as the base word does (pies: piesek [dog: doggie]), a derivational morpheme (here: $-e k$ ) specifies and particularizes the meaning of the base ( $p i e s+e k=$ piesek 'maty pies' [a little dog]). The derivational morpheme in modification constructions performs a semantic function, specifying information about certain features of the object such as its size, e.g., dom-ek $\rightarrow$ dom + maty [house + small], or gender, e.g., student-ka $\rightarrow$ student + kobieta [female] or the features of the subject such as the speaker's attitude towards the object or situation: negative $(p i e s+d u \dot{z} y+b r z y d k i+z l y[\operatorname{dog}+$ large + ugly + fierce $]=p s i s k o)$ or 
positive $-($ pies + maty + tadny + dobry $[\mathrm{dog}+$ smsll + nice + good $]=$ pieseczek $)$ (Grzegorczykowa \& Puzynina, 1984).

Mutation constructions name new objects (phenomena) as to their relations to the predicate expressed by a verb or an adjective, or as to relations to another object (phenomenon) [Grzegorczykowa \& Puzynina, 1984]. The derivational morpheme in mutation constructions forms new lexical units that relate to new phenomena of reality in relation to action (e.g., biegać $\rightarrow$ biegacz [run $\rightarrow$ runner]), an object (thing) (e.g., kawa $\rightarrow$ kawiarz [coffee $\rightarrow$ coffee lover]; okulary $\rightarrow$ okularnik [spectacles $\rightarrow$ person who wears spectacles, 'four-eyes']), or a feature (e.g., brudny $\rightarrow$ brudas [dirty $\rightarrow$ slob, dirty person]) to which they are in some relation (Dokulil, 1979).

In transposition constructions no change takes place in relation to the base word; only the syntactic function of the resulting formation changes e.g.: biegać $\rightarrow$ bieg-anie ([run $\rightarrow$ running] verb-noun). The derivational morpheme (here: -anie) performs an exclusively grammatical function in transpositions.

When emphasizing the semantic structure of derivational constructions and classifying them, Dokulil (1979) provided more arguments for the thesis about the reflection of categorization, performed by the cognitive mind, of phenomena in derivational constructions, which was in turn re-interpreted in the trend of investigations in cognitive linguistics (Szymanek, 1988; Waszakowa, 1996; Grzegorczykowa \& Szymanek, 2001; Szymanek, 1988). From the cognitive perspective, word-formation categories are defined as conceptual categories expressed by derivational means: conceptual (cognitive) categories expressed in a given language by means of special formal exponents (derivational morphemes) in a not fully regular and obligatory manner (unlike grammatical categories, which are characterized by a high degree of regularity) (Grzegorczykowa \& Szymanek, 2001, p. 473).

Polish is one of the languages in which the basic way of expanding the lexicon is by derivation. This consists in forming a new word on the basis of another by changing its morphological structure through such processes as (Grabias, 1980, 1981):

- prefixation, e.g., pisać: na-pisać 'skończyć pisać' [write: finish writing];

- suffixation, e.g., sport: sport-owiec 'ten, kto uprawia sport [sportsman 'one who does sports'];

- changes of the inflectional paradigm, e.g., śpiewać: śpiew 'to, że się śpiewa [sing: singing 'the fact that one sings'] (verb - noun);

- clippings, e.g., [grammar] gramatyka: grama 'ekspresywnie o gramatyce' [expressive term for grammar]';

- morphological alternations, e.g., nos: noch 'ekspresywnie o nosie ['expressive word for nose].

The fundamental and most productive type of derivation, or the most productive word-formation process in Polish, is suffixation. This consists in adding to the root word a derivational morpheme in the form of a suffix (Grabias, 1980, 1981), e.g., [cat] kot: kot-ek 'kot, który jest maty' [cat which is small]; koc-isko 'kot, który jest duży and brzydki' [cat which is large and ugly]; koci-ara 'kobieta, która lubi koty' 
[woman who likes cats]. Suffixal derivatives appear as first in the process of acquisition of word-formation rules (Chmura-Klekotowa, 1971; Haman, 2000, 2003).

A synonymous term for 'derivative' is the term 'derivational construction'. In order to identify a word as a derivational construction it is necessary to establish both a formal and a semantic relationship between the word and the base word e.g. kuchnia - kucharz [kitchen - *kitchener - cook], król - królowa [king - *kingess - queen]. To establish a semantic relation between the base word and a derived word, we use derivational (word-formation) paraphrases. This is a defining statement in which the base word has to be used (Grzegorczykowa \& Puzynina, 1984, p. 316), e.g., nauczyciel to 'ten, kto naucza' [teacher is one who teaches].

Apart from forming a paraphrase, the proof of understanding the construction is the ability to make an explication of the features that make up its structural meaning $^{1}$ (with the elements of real meaning ${ }^{2}$ ) without the need to produce a defining statement in the form of a paraphrase. The description of meaning through producing an explication is the presentation of constituents of the situation named by this expression. To explicate the meanings of expressions is to assign to them equivalent meanings that are more analytical (Grzegorczykowa, 1995, p. 10). In reference to derivationally divisible words it denotes identification of the base word and recognition of the meaning of the derivational morpheme (e.g., in answer to the question about each constituent of the formation).

\section{Derivational constructions in the lexicon of children with hearing loss}

Since there are undeniable lexical and grammatical difficulties of children with hearing loss, the difficulties in the formation of new words may appear obvious and perhaps this is why they are disregarded in the descriptions of language skills of children with hearing loss. There are few studies in Polish that would deal with the problems of the development of the awareness of derivational word structure in the process of language acquisition (Chmura-Klekotowa, 1979; Haman, 2000a,b, 2003). There are no studies into the word-formation awareness in children with hearing loss. These problems are usually mentioned when analyzing the grammar system (Rakowska, 1992; Krakowiak, 1995). The object of investigations is exclusively diminutive constructions (illustrated with several selected examples). Conclusions that follow from the studies are of exclusively qualitative nature.

The recorded errors made by primary school students (taught by traditional methods) in the production of diminutives cover (Rakowska, 1992): incorrect use of the diminutive morpheme, e.g., [plate] talerz - talerz-ek (instead of talerz-yk [small plate]); addition of declensional endings instead of derivational morphemes,

\footnotetext{
${ }^{1}$ Structural (word-formation) meaning is one that follows from the structure of the word-formation construction. This is the sum of meanings of the base word and the derivational morpheme (Grzegorczykowi, 1982), e.g. sarenka - mała sarna [little roe deer].

${ }^{2}$ Real meaning is vested with words as lexical units (Grzegorczykowa, 1982), e.g., sarenka [little roe deer] - zwierze żyjące w lesie [an animal living in the forest].
} 
e.g.,[bird] ptak - ptaka (instead of ptasz-ek [birdie]); addition of the derivational morpheme to the unchanged noun form, e.g., [ball] pitka - pitka-rek (instead of pit-eczka [small ball]); use of un incorrect derivational morpheme added to an incorrectly identified derivational base, e.g., [ball] pitka - pit-ek (instead of pit-eczka).

In the case of children with hearing loss, taught by the phonogesture (Cued Speech) method (Krakowiak, 1995) ${ }^{3}$, they first of all form many neologisms showing they identify the function of diminutive morphemes, e.g. zegaraszek, serduczko (instead of zegareczek [small watch], serduszko [little heart]); they add random elements instead of derivational morphemes: serduk-owe (instead of serduszko); they use inflectional endings instead of derivational morphemes: rowerz-e (instead of rower-ek [tiny bicycle]). Children who 'phonogesture' (cue) demonstrate a satisfactory level of understanding diminutives. In general, as studies have shown, they achieve far better results than children taught in the traditional way.

Studies on the knowledge of derivational constructions other than diminutive ones among children with hearing loss have not yet been started.

\section{The object of investigation}

The object of the experiment presented in this article was broadly defined. Analyses covered suffixal noun derivatives that represented individual word-formation categories. The choice of suffixal nouns was motivated by the frequency criterion and the observed developmental regularities concerning their acquisition. Nouns are the most numerous class of parts of speech, constituting the core of the lexicon (Sambor 2001, pp. 509-510). They are the most diversified category of words, both semantically and formally, derivatives being a large part of them. Noun derivatives are the most numerous in the lexicon of children. They appear first in the process of language acquisition. According to the studies by Chmura-Klekotowa (1971) they constitute $50 \%$ of all neologisms, their formal exponent being very often a suffix.

In order to take into account the different degrees of complication of the semantic structure, the object of investigation are nouns derived from nouns, verbs, and adjectives. I adopted the division of derivative formations on the basis of the semantic functions of derivational morphemes. Derived nouns were therefore divided, in accordance with M. Dokulil's classification [1979], into modification derivatives, mutation derivatives and transposition derivatives ${ }^{4}$. Within modification and transmutation I classified them according to the system of derivational categories proposed by R. Grzegorczykowa (1982).

\footnotetext{
${ }^{3}$ Phonogestures are special hand movements or shapes ('cues') that combine with speaking to assist reading of speech from the lips. They are the Polish adaptation of the Cued Speech method well known all over the world (Krakowiak, 1995).

${ }^{4}$ Transposition categories were taken into account in the investigation procedure but were omitted in the analyses. The collected material showed that, in order to motivate the child to form transposition constructions, it is necessary to use a different research instrument than the one designed and used to study modification and mutation categories.
} 
Out of modification categories I chose as the object of analysis:

- diminutive names (nouns), e.g., [house] dom: dom-ek 'dom, który jest maty' [house that is small];

- expressive names (nouns) - augmentative and hypocoristic (endearing), e.g., [cat] kot: koc-isko 'kot, który jest duży and brzydki' [cat that is large and ugly]; koteczek 'kot, który jest bardzo maty and tadny' [cat that is very small and nice];

- feminative names (nouns), e.g., [male cook] kucharz: kuchar-ka 'kobieta, która jest kucharzem' [woman who is a cook].

Out of mutation categories I chose:

- names of personal agents (Agents), e.g., [ball] pitka: pitk-arz [footballer] 'ten, kto gra w pitkę [one who plays football];

- names of instruments (Instruments), e.g., [open] otwierać: otwier-acz [opener] 'to, czym się otwiera, e.g. butelki' [that which one opens with, e.g., bottles];

- names of products and objects of actions (Patients), e.g., [wind] wiatr: wiatr-ak [windmill] 'to, co jest poruszane przez wiatr' [that which is driven by wind];

- names of feature carriers (Attributive Nouns), e.g., [fat] gruby: grub-as [fat person, fatty] 'ten, kto jest gruby [someone who is fat]';

- place names (names of locations or Locative Nouns), e.g., [tea] herbata: herbaci-arnia [tea-house] 'miejsce, gdzie pije się herbatę' [the place where one drinks tea].

The choice of nouns for tests was first of all determined by the distribution criterion. The questionnaire thus contains the words that a child who starts school should know and those that a child with hearing loss, attending junior high school should have in his/her lexicon ${ }^{5}$. The choice of derivational morphemes was primarily determined by their productivity and frequency in general Polish and in the children's lexicon ${ }^{6}$.

\section{Test groups}

The tests were carried out in three 30-child groups - two experimental and one control group. The experimental groups consisted of children with hearing loss - deaf and hard-of-hearing; the control group - hearing children. The test proper was preceded by a pilot test in a group of 15 children with hearing loss. The characteristics of the groups tested are as follows:

\footnotetext{
${ }^{5}$ For this purpose, selecting word-formation constructions for investigation, I used basic dictionaries of Polish and frequency studies, including those taking into account the theme criterion, handbooks of Polish for foreigners, handbooks of Polish for deaf children, and linguistic studies on the lexicon of children, and handbooks dealing with word formation.

${ }^{6}$ Derivational morphemes were selected on the basis of results of investigations published in linguistic studies, inter alia by. H. Satkiewicz, Produktywne typy slowotwórcze wspótczesnego języka polskiego [Productive derivational types in Contemporary General Polish] (1969); M. Chmura-Klekotowa, Neologizmy stowotwórcze w mowie dzieci [Derivational Neologisms in the Speech of Children] (1979).
} 
Group I - 30 hearing children starting education in primary school, first grade students. Their language awareness is of natural character, i.e. it was acquired through experience rather than through a systematized teaching process (Kwarciak, 1995).

Group II - 30 hard-of-hearing first- or second-grade gimnazjum students with a diagnosed profound hearing loss, exceeding $90 \mathrm{~dB}$ (Skarżyński et al., 1999). The children finished the first stage of education (primary school). They are taught with the use of traditional oral methods ${ }^{7}$. They attend school for hard-of-hearing children. They speak (to a limited extent) and use the sense of hearing (hearing aids). They mainly use Polish, only some of them know the sign language. They generally come from hearing families, they stay in the environment of hearing and speaking people. The children had a diagnosed hearing loss usually at the age of two or three, therefore they started wearing hearing aids late (aged 2-5).

Group III - a similar group of 30 first- or second-grade students in a gimnazjum for deaf children with a diagnosed profound hearing loss. The children also finished the first stage of education. They are taught using the sign language. They attend school for deaf children. They do not speak and do not use the hearing sense (they do not wear hearing aids). They communicate by means of the Polish sign language. They stay in the environment of deaf people, using sign language. They come from hard-of-hearing families, where the members communicate with the sign language, or from hearing but neglected families with a low social and financial status. They are usually deaf from birth and were provided with hearing aids late (at the age 2-5).

\section{The research instrument}

The instrument serving to collect material was a word-formation questionnaire specially designed for the purpose. It was designed to test two types of skills: comprehension (decoding) and production of (encoding) derivational constructions. Each skill was tested in two ways.

TASK I (TI) - assessment covered the ability to decode (understand) derivational constructions belonging to particular word-formation categories -

Technique 1 (T1) - the ability to decode constructions in the form of derivational paraphrase (ability to produce a paraphrase), e.g.:

- Co to jest domek? [What is a domek \{little house\}]

- Co to jest ptaszysko? [What is a ptaszysko \{ugly bird\}]

- Co (kto) to jest kłamca? [What (who) is a liar]

\footnotetext{
${ }^{7}$ Oral (oral-auditory, multi-sensory) methods consist in the use of all senses in teaching speech. They are based on improving the impaired hearing organ (inter alia owing to the fact that children wear hearing aids) and improving lip reading. In practice one can speak partly about the use of the principles of total communication: the use, in communicating with persons with hearing loss, of all means available, the native language in its spoken and written form, gestures, facial expressions, dactylology, visual aids, technical means, natural sign language, and the language-sign system (Krakowiak, 2003).
} 
Figure 1.The structure of the research instrument

\begin{tabular}{|c|l|l|}
\hline $\begin{array}{c}\text { TASK I } \\
\text { Comprehension of } \\
\text { constructions }\end{array}$ & Technque 1 & Producing a derivational paraphrase \\
\cline { 2 - 3 } & Technique 2 & $\begin{array}{l}\text { Explicating semantic features that make up the } \\
\text { structural meaning of a construction }\end{array}$ \\
\hline $\begin{array}{c}\text { TASK II } \\
\text { Production of con- } \\
\text { structions }\end{array}$ & Technique 1 & On the basis of derivational paraphrase \\
\cline { 2 - 3 } & Technique 2 & $\begin{array}{l}\text { On the basis of semantic features that make the } \\
\text { structural meaning of a construction }\end{array}$ \\
\hline
\end{tabular}

- Co (kto) to jest herbaciarnia? [What (who) is a tea-house]

Technique 2 (T2) - the ability to decode constructions in the form of semantic features that make up their structural meaning. Semantic features had to be written in the spaces in the table, provided with appropriate questions. Here are some examples of modification constructions (diminutive and augmentative):

\begin{tabular}{|c|c|c|}
\hline Name & What is this? & What is it like? \\
\hline Domek & ……….... & 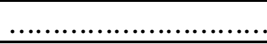 \\
\hline Ptaszysko & ................. & …........................... \\
\hline Krzesełko & & \\
\hline
\end{tabular}

[domek - little house, ptaszysko - ugly bird, krzesełko - little chair]

Examples of mutation constructions (names of an object, place, instrument):

\begin{tabular}{|l|c|c|c|c|c|}
\hline Name & woman & man & object & place & What does it do? \\
\hline Mrożonka & & & $\ldots \ldots \ldots$ & & $\ldots \ldots \ldots \ldots$ \\
\hline Herbaciarnia & & & & $\ldots \ldots \ldots$ & $\ldots \ldots \ldots \ldots$ \\
\hline Grzejnik & & & $\ldots \ldots \ldots$ & & $\ldots \ldots \ldots \ldots$ \\
\hline
\end{tabular}

[mrożonka - frozen food, herbaciarnia - tea-house, grzejnik - heater]

TASK II (TII) - assessment covered the ability to produce (encode) derivational constructions belonging to particular word formation categories -

Technique 1 (T1) - the ability to produce constructions on the basis of a derivational paraphrase, e.g.:

- Kot, który jest mały to... [A cat that is small is a....]

- Pies, który jest bardzo mały, bardzo ładny i dobry to... [A dog that is very small, very nice and good is a...]

- Pan, który biega to... [A man who runs is a...]

- Sklep, w którym ludzie kupują książki to... [A store where people buy books is a...] 
Technique2 (T2) - the ability to produce constructions on the basis of semantic features that make up its structural meaning. Individual words of an explication were placed in the table spaces. The base word (in bold face) was shown to the children. Here are some examples of modification constructions (diminutive, hypocoristic, and feminative):

\begin{tabular}{|l|c|c|}
\hline Name & What is it like? & What is it called? \\
\hline Kot $[\mathrm{cat}]$ & tiny & $\ldots \ldots \ldots \ldots \ldots$ \\
\hline Pies $[\mathrm{dog}]$ & very small and good & $\ldots \ldots \ldots \ldots \ldots$ \\
\hline Aktor $[$ actor] & is a woman & $\ldots \ldots \ldots \ldots \ldots$ \\
\hline
\end{tabular}

Examples of mutation constructions (names of agent, place, and instrument):

\begin{tabular}{|c|c|c|c|c|c|}
\hline woman & man & object & place & what does it/s/he do & what is it/s/he called? \\
\hline & + & & & runs & $\ldots \ldots \ldots \ldots \ldots$ \\
\hline & & & + & one buys books in & $\ldots \ldots \ldots \ldots \ldots$ \\
\hline & & + & & we open bottles with & $\ldots \ldots \ldots \ldots \ldots$ \\
\hline
\end{tabular}

\section{Research material}

Research material consisted of a total of 14460 units, which were:

- 7200 paraphrases and explications of semantic features that made up the structural meaning of constructions representing particular word-formation categories;

- 7260 derivational constructions (or other lexical units that emerged as a result of attempts to produce constructions) formed on the basis of a paraphrase or semantic features explicated from the structural meaning of formations ${ }^{8}$.

\section{The ability to interpret modification constructions (TI)}

The skills in interpreting modification constructions - production of a derivational paraphrase and explication of features making up the structural meaning of a construction - are as follows in the individual test groups.

\section{Production of paraphrases of modification constructions (T1)}

Producing paraphrases of modification constructions turned out to be a difficult task both for the hearing first-graders and junior high students with hearing loss.

(1) Hearing children produced many times more paraphrases than children with hearing loss, apart from one exception: diminutive constructions (however, they decoded the meaning of diminutives in the form of semantic features without any problems) $)^{9}$.

\footnotetext{
${ }^{8}$ The author used the MS Excel 2000 program for quantitative analyses.

${ }^{9}$ This lower result of diminutive paraphrase production in the hearing children's group can therefore be treated only as a suggestion for the methodology of studies in the area of word-formation: younger children require more instructions that guide them towards formal relations between words.
} 
Figure 2. Interpretation of modification constructions by hearing $(\mathrm{H})$, hard-of-hearing $(\mathrm{HOH})$ and deaf $(\mathrm{D})$ children

Ability to decode modyfication constructions by children: hearing $(\mathrm{H})$, hard-of-hearing $(\mathrm{HOH})$ and deaf $(\mathrm{D})$

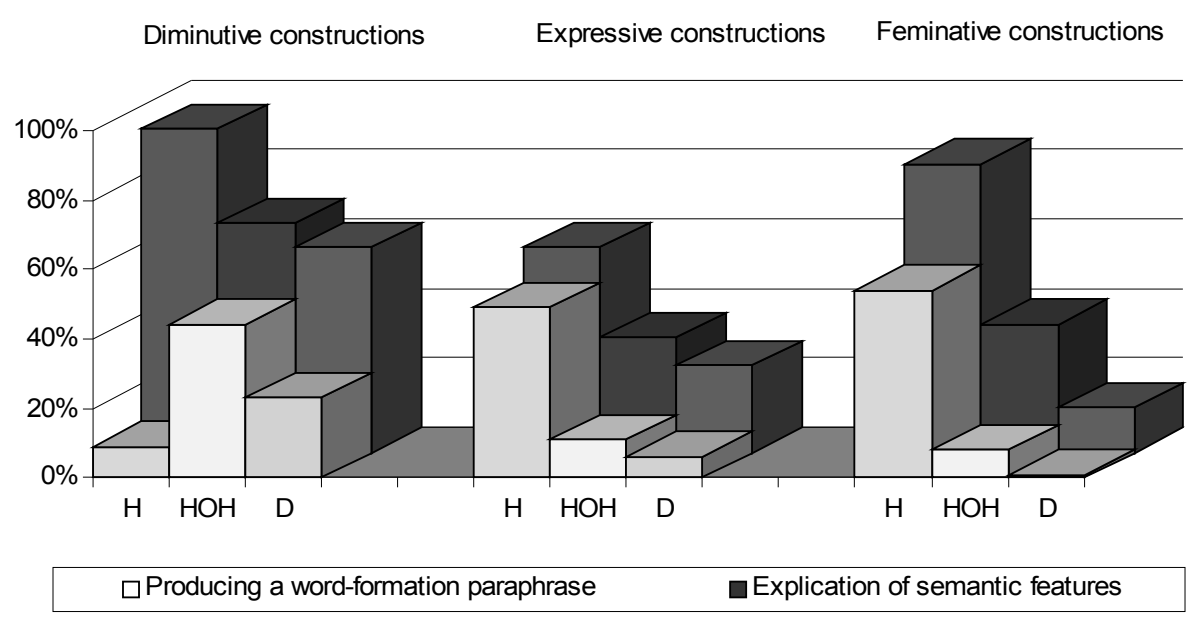

(2) Hard-of-hearing children produced more correct paraphrases of modification constructions than deaf children. They coped comparatively best with paraphrases of diminutives (e.g. Co to jest [what is a] domek? To jest mały dom [it is a little house]). Correct paraphrases accounted for $44 \%$ of possible answers.

(3) Deaf children could not practically produce defining statements for expressive and feminative constructions. Like hard-of-hearing children they managed to cope, although to a very small degree (the correctness level attaining $23 \%$ ), only with paraphrases of diminutives.

Explication of semantic features of modification constructions (T2)

Explication of semantic features that made up the structural meaning of modification constructions caused fewer difficulties for children in all the groups tested than production of a derivational paraphrase.

(1) Hearing children showed they learned the skill of decoding the meanings of diminutive (e.g. Co to jest konik? [What is a little horse?] Dziecko konia [A horse's child] Fakie jest? [What is it like?] Malutkie [Tiny]) and feminative constructions (e.g. Kto to jest tygrysica? [What is a tigress?] Tygrys [A tiger] Faki jest? [What is it like?] Który jest taki dobry, rodzi małe tygrysy [One that is so good, it produces little tigers]). The level of accuracy exceeded $90 \%$ for diminutives and $80 \%$ for feminative nouns. The children had somewhat 
worse results with expressive constructions (but, which is important, they interpreted them in terms of expressive signs), e.g., Co to jest kocisko? [What is a kocisko ?] Kot [A cat] Jaki jest? [What is it like?] Stary i brzydki i nie jest mity [Old and ugly and not nice].

(2) Hard-of-hearing children performed best in interpreting diminutives $(66 \%$ of correct explications). They also demonstrated a far better knowledge of feminative nouns than their skill in producing paraphrases would indicate. They did the poorest with expressive constructions: they essentially failed to identify augmentative constructions (e.g., Co to jest kocisko? [What is a kocisko?] Kot [A cat] faki? [What kind?] Duży [Large]), while they generally interpreted hypocoristic constructions as diminutive (e.g., Co to jest kotuś? [What is a kotuś?] Kot [A cat] faki jest? [What is it like?] Mała [Small]).

(3) Deaf children also showed a fairly good understanding of diminutives (almost 60\% of correct explications). Despite being asked supporting questions, they identified the category of 'feminine' only to a small extent (13\%). This was probably influenced by the characteristics of the language in which they basically communicate - the sign language. In the Polish sign language the category of gender is absent while information about gender is communicated through analytical constructions, i.e. by adding the sign 'male' or 'female' to another sign (Mrozik, 2003, p. 72). Deaf children practically did not give any expressive meaning either to endearing words or to augmentatives. Only very few deaf children were able to decode expressive constructions (especially those with a pejorative meaning), e.g. Co to jest ptaszysko? [What is a ptaszysko?] Ptak [A Bird] Jaki? [What kind?] Duży [Large].

\section{The ability to produce modification constructions (TII)}

Differences in the ability to produce derivational constructions by hearing, hard-of-hearing, and deaf children are manifested more distinctly than differences pertaining to interpretation skills. One can observe a great disparity between the results obtained by hearing children and the results obtained by children with hearing loss.

Hearing first-graders produced more than twice as many modification constructions than hard-of-hearing junior high students, who in turn coped several times better in producing modifications than their deaf peers.

(1) Hearing children had certain problems only with expressive constructions ${ }^{10}$. It was hardly difficult for them to construct diminutives and feminatives. Feminative constructions turned out to be the easiest; the percentage of

\footnotetext{
${ }^{10}$ I treat the results of the questionnaire survey on expressive formations as indicating the need to introduce some other methodological solution for investigating them. In order to be motivated to produce expressive formations children should be faced with a situation that would involve them emotionally and make them express their subjective attitude to the phenomena presented. It is therefore necessary to provide stimuli evoking positive or negative emotions (see Grabias, 1980).
} 
Figure 3. Production of modification constructions by hearing $(\mathrm{H})$, hard-of-hearing $(\mathrm{HOH})$ and deaf (D) children

Ability to encode modification constructions by children: hearing $(\mathrm{H})$, hard-of-hearing $(\mathrm{HOH})$ and deaf $(\mathrm{D})$

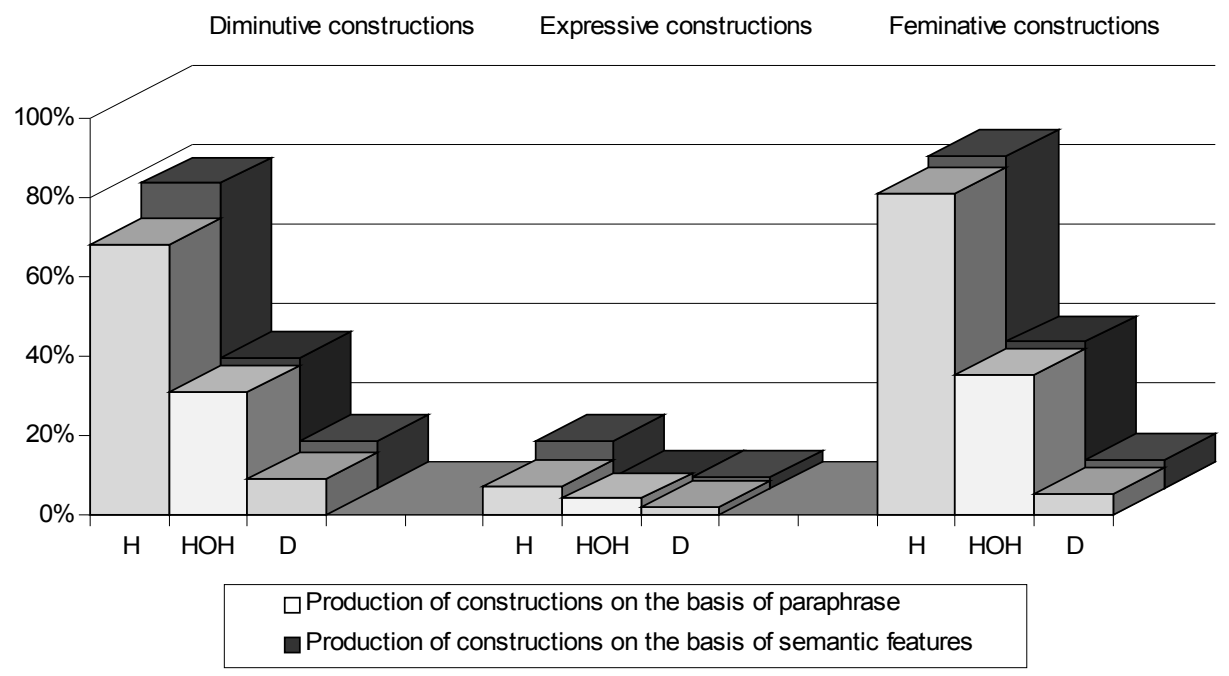

correct answers attained the level of $80 \%$, but they had only slightly lower results for diminutive productions $(77 \%)^{11}$.

(2) Children with hearing loss, like hearing ones, found it most difficult to produce expressive constructions, and less difficult - to produce diminutive and feminative constructions. The latter - but as with hearing children only with a slight advantage - turned out to be the easiest to produce by those with hearing loss, attaining the level of $37 \%$.

(3) Deaf children could not produce modification constructions. We might say that they showed only a poor ability to produce diminutives, the level of accuracy being barely $12 \%$. Unlike hard-of-hearing children, deaf children could not form feminine nouns (there were only single correct formations, e.g., Kobieta aktor [woman actor] - aktorka [actress]).

In all groups, production of expressive constructions was the poorest. Hearing children produced hypocoristic and augmentative formations. In both groups of children with hearing loss I recorded only single examples of hypocoristic formations (e.g., Bardzo maty and tadny but [A very small and nice shoe - buciczek, butuś $[\approx$ bootee] $)$ and not a single augmentative construction.

\footnotetext{
${ }^{11}$ The slightly lower results pertaining to constructing diminutives was probably caused by the use in the questionnaire of the animal names as the base words, from which the children constructed the nouns for young creatures instead of diminutives, identifying the two word-formation categories as the same ( (mały = młody [small=young]), e.g. Kura, która jest mała to kurczątko [hen which is small is a chicken] (instead of kurka [little hen]).
} 
Figure 4. Modification constructions - decoding and encoding. Hearing children $(\mathrm{H})$, hard of hearing children $(\mathrm{HOH})$, and deaf children (D)

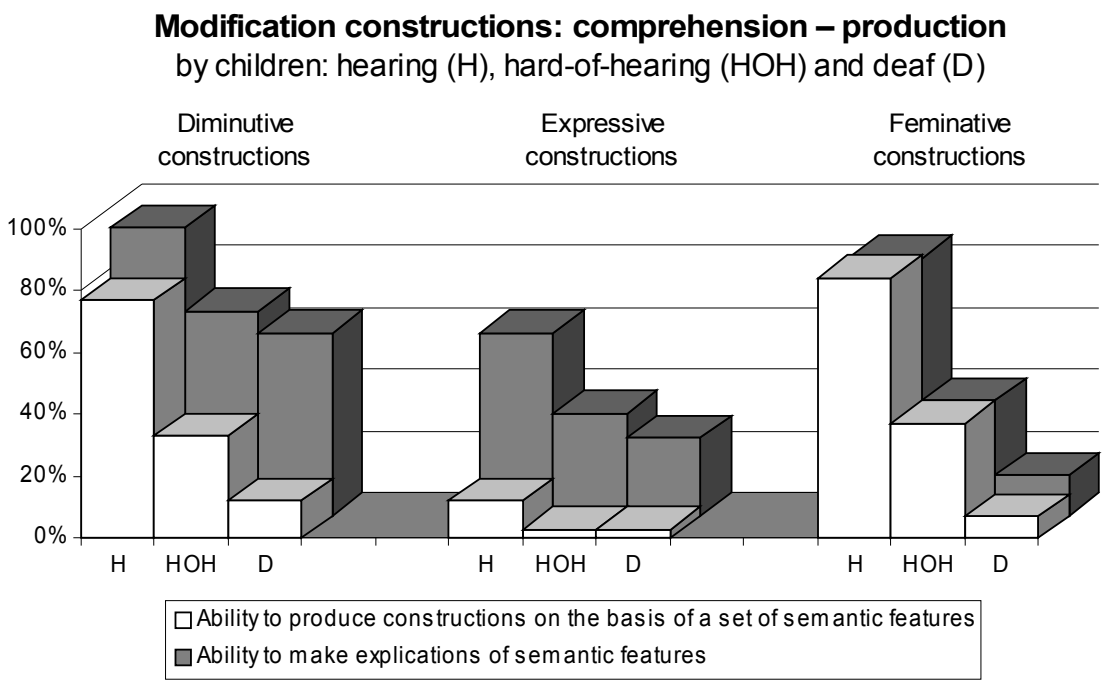

\section{Decoding and encoding of modification constructions}

To sum it up, the level of decoding or understanding modification constructions exceeded the level of coding or producing, which is in accordance with the regularities of language development: comprehension of words precedes speaking (Benedict, 1979).

The greatest differences between the ability to decode and encode were recorded in the deaf children group, far smaller - in the hard-of-hearing children group, and the smallest - in the hearing children group.

(1) Hearing children exhibited an understanding of formations which only slightly exceeded the ability to produce them (apart from expressive constructions) ${ }^{12}$.

(2) In the hard-of-hearing children group, a great disparity between comprehension and production was reported only in the case of feminative nouns, which were the least difficult for children to produce.

(3) In the deaf children group the greatest difference between the ability to understand and to produce was reported in the diminutive category, one that the children interpreted comparatively well.

\footnotetext{
${ }^{12}$ There was a considerable disparity between comprehension and production of expressive constructions in all groups, which once again confirms the need to adopt some other methodological solutions in this case.
} 
Figure 5. Interpretation of mutation constructions by hearing $(\mathrm{H})$, hard of hearing $(\mathrm{HOH})$ and deaf (D) children

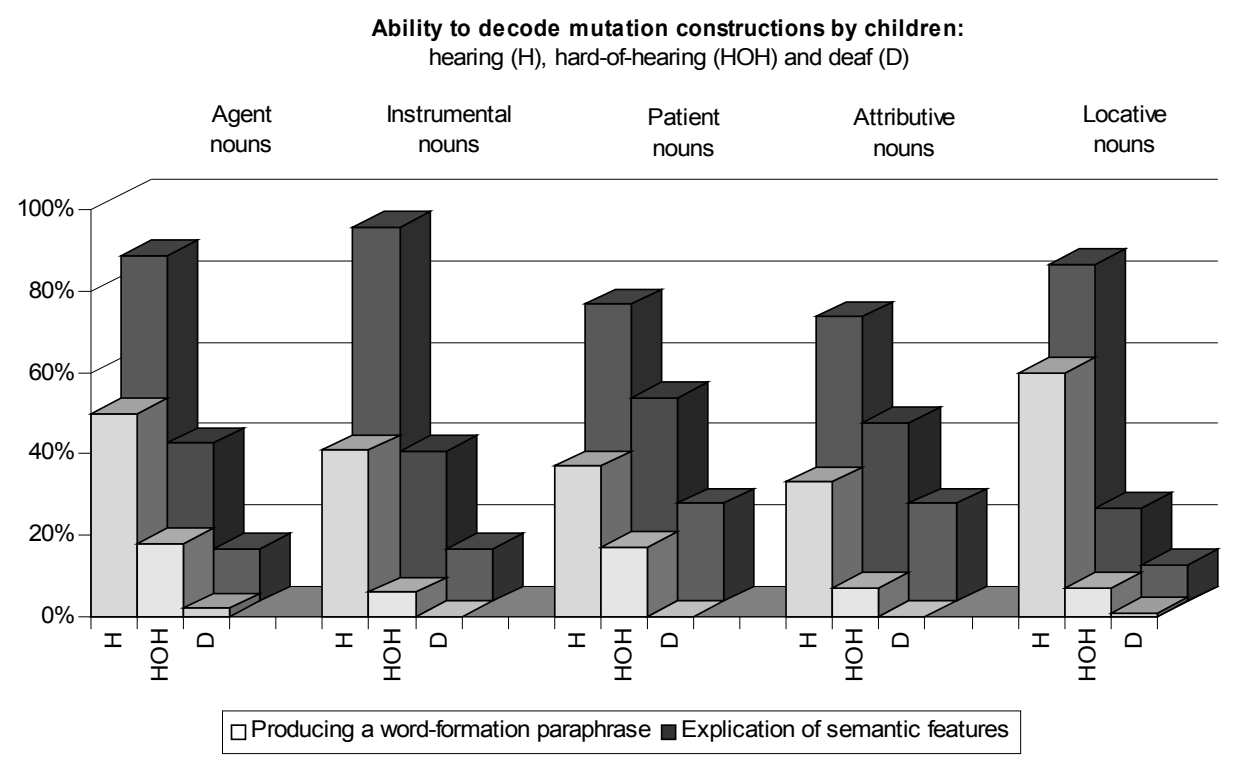

\section{The ability to interpret mutation constructions (TI)}

Understanding of mutation constructions by hearing $(\mathrm{H})$, hard-of-hearing $(\mathrm{HOH})$ and deaf (D) children looks as follows:

Production of derivational paraphrases of mutation constructions (T1)

Producing paraphrases of mutation constructions was difficult for all children, both for those with hearing loss and the hearing ones.

(1) Hearing first-graders found it the easiest to produce paraphrases of locative nouns, the level of accuracy being $60 \%$ (close to the level for doers of action). The next to follow were the names of doers of action (50\%) and names of instruments (41\%). The greatest problem for the children were the paraphrases of names denoting feature carriers (many contained the elements of real meaning other than those conventionally attributed to a given lexical unit, e.g., Kto (co) to jest brzuchacz? [Who (what) is a brzuchacz? \{big-bellied man\}] To taki pan, co pokazuje brzuch [This is a man who shows his belly] (instead of: ma gruby brzuch [he has got a big belly]).

(2) Hard-of-hearing children were able to correctly produce only the paraphrases of names of products and objects (however, they often used semantic elements inconsistent with the established conventional meaning), e.g., Co (kto) to jest leżak? [What (who) is a deckchair [in Polish literally a lier $<$ lie 
on]] Ktoś, kto leży na leżaku [Someone who lies on a deckchair] (instead of: coś, na czym leżymy [something we lie on]) and the paraphrases of doers of action. However, they never reached the level of more than $20 \%$ of correct answers. The paraphrases of the other categories were present in very modest numbers.

(3) Deaf children were unable to produce paraphrases of mutation constructions. I recorded only several isolated paraphrases of individual formations (with syntactic errors), e.g,. Kto (co) to jest pitkarz? [Who (what) is a pitkarz \{footballer?\}] Pitka to jest chtopiec [The ball is a boy].

Explication of semantic features of mutation constructions (T2)

To explicate semantic features that made up the structural meaning of mutation constructions was less difficult for hearing, hard-of-hearing, and deaf children than to produce derivational paraphrases.

(1) Hearing children found it easiest to make explications of features that made up the names of instruments: their level of understanding exceeded $90 \%$. Right after them followed the names of doers of action and locative nouns. The level of accuracy never fell below $70 \%$ (the level of decoding of names of feature carriers, and products and objects).

(2) Hard-of-hearing children, in turn, did best with decoding names of products and objects, fairly well with attributive nouns (correct explications constituting ca. half of the answers). They had the greatest problems with the analysis of locative nouns when correct explications constituted only one fourth of the answers possible).

(3) Deaf children, like the hard-of-hearing, showed a certain skill in explicating names of products and objects, and attributive nouns. The level of accuracy, however, did not exceed $25 \%$. They performed the poorest, also like hard-of-hearing children, with locative nouns - only $9 \%$ of correct explications.

In the decoding of mutation constructions there were similarities between hardof-hearing and deaf children, which contrasted with the trend observable in the hearing children group. The categories that were the most difficult for the hearing children, i.e. names of products and objects and the names of feature carriers, turned out to be those that were comparatively easiest the least difficult for the children with hearing loss to decode. The easiest categories for hearing children - locative names - turned out to be the most difficult for hearing children.

\section{The ability to produce mutation constructions (TII)}

There were very great differences between the particular children groups in the production of individual mutation categories.

Hearing children showed skills that were even several times better than the skills of children with hearing loss. Deaf children were practically unable to produce 
Figure 6. Production of mutation constructions by hearing $(\mathrm{H})$, hard of hearing $(\mathrm{HOH})$ and deaf (D) children

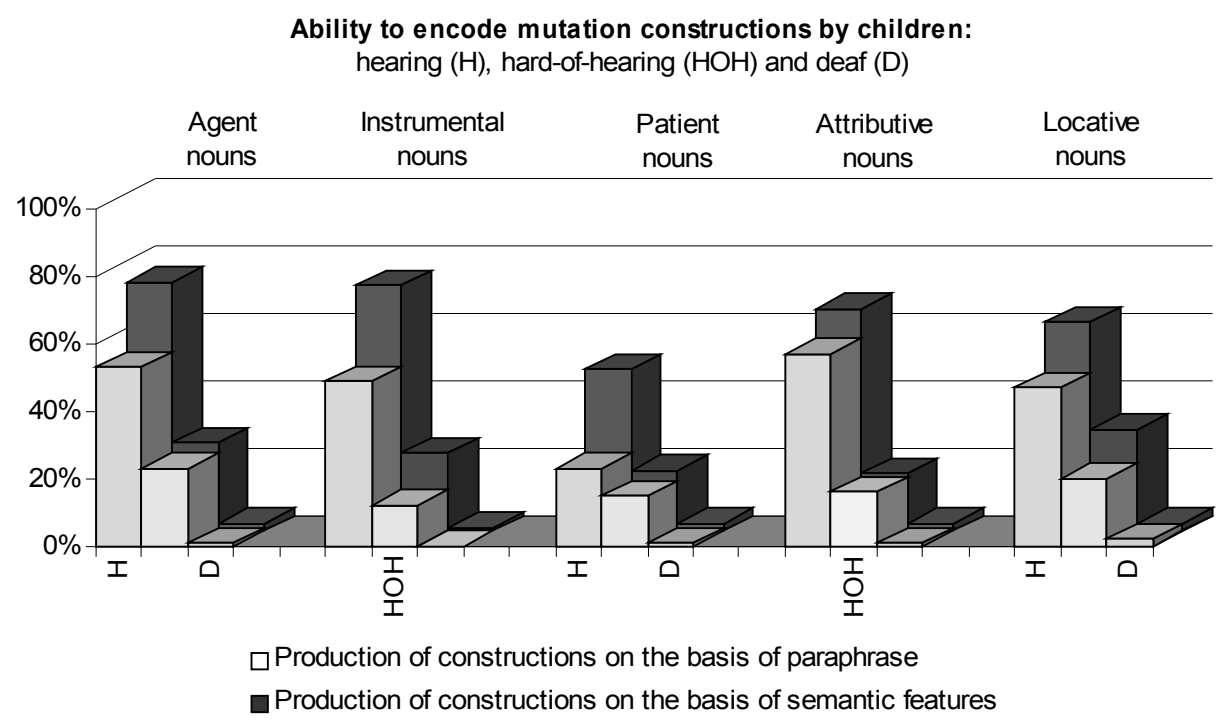

mutation constructions. Disparities between the results obtained in the different groups varied depending on word-formation category.

The number of constructions produced on the basis of semantic features (T2) was higher than the number of constructions produced on the basis of paraphrase. These differences were the highest in the hearing group. In both groups of children with hearing loss they were not so pronounced since the children produced a constant (small) number of formations regardless of the technique applied.

(1) Hearing first-graders did not have greater difficulties in producing mutation constructions $^{13}$. Certain difficulties appeared essentially only with producing names of products and objects (less than half of the correct formations). The best results were obtained in producing names of doers of action and names of instruments, the level of accuracy exceeding $70 \%$.

(2) Hard-of-hearing first-grade students coped comparatively well with producing locative nouns and names of doers of action: ca. $30 \%$ of constructions were produced correctly. Names of carriers of features and names of products and objects turned out to be the most difficult (less than 20\%). In general, the level of production of all mutation constructions was similar, comparably low.

(3) Deaf children practically did not produce mutation constructions at all.

13 This result appeared somewhat lower because of problems with producing single constructions by a greater number of children. This may suggest that if some other base words had been chosen, the average score of correct mutation constructions production would have been higher. 
Figure 7. Mutation constructions - decoding and encoding. Hearing children $(\mathrm{H})$, hard of hearing children $(\mathrm{HOH})$, and deaf children (D)

\section{Mutation constructions: comprehension - production by children: hearing $(\mathrm{H})$, hard-of-hearing $(\mathrm{HOH})$ and deaf $(\mathrm{D})$}

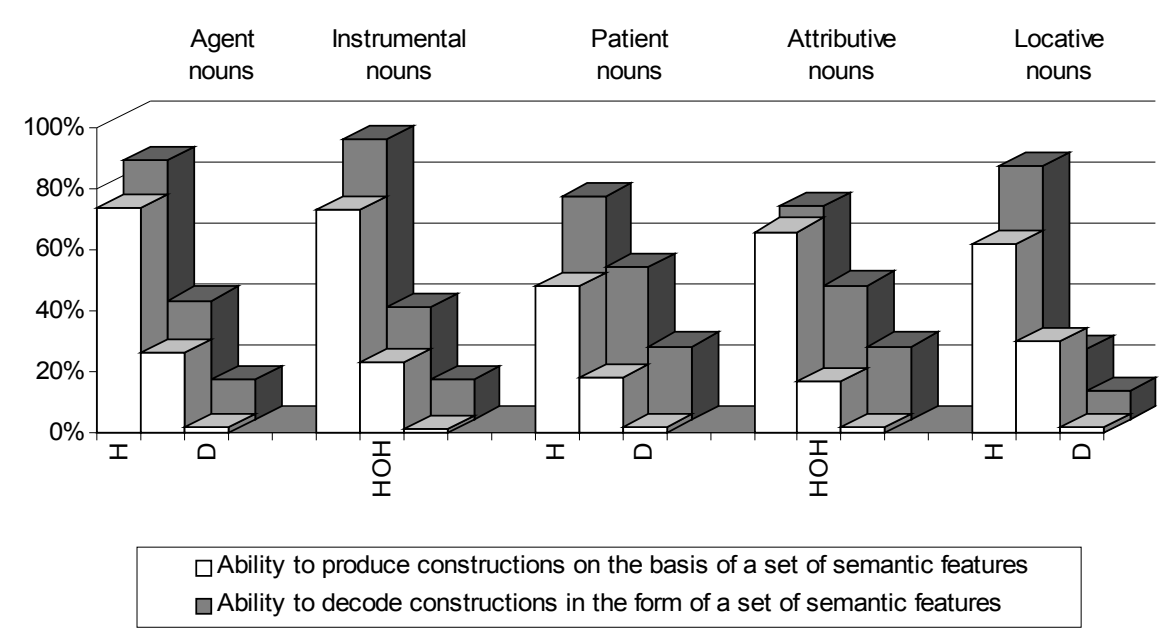

\section{Decoding and encoding of mutation constructions}

The level of comprehension of individual mutation categories exceeded the level of production in all test groups.

The only exception to this rule determined by developmental principles was the category of locative nouns in the hard-of-hearing children group. Hardof-hearing children better produced locative nouns than their decoding skills would have indicated. This might have been caused by the selection of words for the questionnaire. The locative nouns that the children were expected to produce belonged to those frequently used and therefore probably well known to the children. The locative nouns that the children were expected to decode turned out to be far more difficult. They were produced from word forms not used in colloquial language (e.g., jadalnia [dining room] 'tam, gdzie się jada' [where one eats /regularly/, colloquially eats ' $j e$ ']), consequently these did not meet the criterion for transparency of meaning (E.V. Clark, 1984; 1993). Additionally, in the words analyzed, morphological alternations occurred, which made it difficult for the children to decode them: the condition of simplicity of form was not fulfilled (E.V. Clark, 1993; Clark \& Berman, 1984). The observed predominance of the ability to produce over the ability to comprehend may prove that hard-of-hearing children are only starting to learn the rules 
governing the acquisition of derived nouns (E.V. Clark, 1980; 1993; Clark \& Berman, 1984) $)^{14}$.

The relations between the ability to interpret and the ability to produce mutation constructions in particular children groups are as follows:

(1) Hearing children produced most easily the constructions that they had first decoded best. These were the names of instruments and doers of action or in general agent/doers and agent/receivers (personal and impersonal). What proved the most difficult was to produce names of products and objects - constructions that also caused somewhat more problems with interpretation.

(2) The group of hard-of-hearing children did not confirm this regularity. Constructions that were decoded best (names of products and objects and names of feature carriers) were produced with the greatest difficulty while those with the poorest decodability (locative nouns) caused the least problems in their production.

(3) Deaf children were not able to produce mutation constructions. They did comparatively best, like hard-of-hearing children, with interpreting names of products and objects and names of feature carriers, however, this was not reflected in their skills in producing formations.

\section{Summary}

Hard-of-hearing and deaf children showed a better knowledge of modification categories than mutation ones, which confirms the regularities observed in the language development of hearing children (Chmura-Klekotowa, 1971; Haman, 2000a, 2000b, 2003). The high level of decoding modification constructions in the two groups of children with hearing loss was first of all determined by their skills in interpreting diminutives. A disparity between the two categories was marked more strongly in 'production' than in 'comprehension' tests. The level of comprehension of the modification and mutation categories was similar. There were even mutation constructions that proved to be better understood than modification ones.

The task of production of derivational paraphrases of modification constructions yielded results that were far lower than the average results concerning the ability to explicate semantic features making up the structural meanings of constructions. Hearing children produced on average half the number of paraphrases than explications. The averaged numbers of paraphrases of modification and mutation constructions produced by hearing children were similar. In both groups of hardof-hearing children a disparity between the number of formations decoded in the form of semantic features and the number of correctly constructed paraphrases of

14 The realization by children with hearing loss of individual rules governing the acquisition of derived words distinguished by E.V. Clark requires separate analyses and goes beyond the scope of this study. However, the phenomena observed indicate the need to start observations in this direction. Additionally, they are a highly significant methodological guideline: the rules of acquisition of derived words distinguished by E. V. Clark should be a criterion taken into account in selecting words for test trials. 
them was far greater than in the hearing children group, especially with mutation categories. Hard-of-hearing children produced on average barely $10 \%$ of paraphrases of mutation constructions while deaf children could not cope with this task (1\%).

Here is the summary of the results of the investigations analyzed in the present article.

Hearing children correctly interpreted on average $90 \%$ of modification constructions and $80 \%$ of mutation constructions. They showed, however, that, as with modification categories, they were able to equally well decode some of the mutation categories, i.e., names of instruments and doers of actions and locative nouns, paraphrases of which they produced the most.

Hearing children produced on average $80 \%$ of modification constructions and $65 \%$ of mutation constructions. They found it easiest to produce diminutive and feminative constructions from modification categories, and the names of agent/doers and /receivers (doers of actions and instruments) out of mutation categories. The number of correctly produced names of doers of actions and instruments were approximately to the number of correctly produced modification formations. There is a correlation between the abilities to decode and encode.

Hard-of-hearing children correctly interpreted on average $50 \%$ of modification constructions and $40 \%$ of mutation constructions. They coped best with decoding diminutive constructions (both in the form of paraphrase and in the form of semantic features). They interpreted the other modification constructions on a somewhat lower level than the level of understanding mutation constructions. They decoded best the names of products and objects and the names of feature carriers (as well as the names of doers of actions, paraphrases of which they produced the most).

In the hard-of-hearing group the difference between correctly produced modifications and mutation constructions was somewhat smaller than in the hearing children group. The hard-of-hearing produced on average 35\% of modification constructions and $25 \%$ of mutation constructions. The level determined by the ability to produce modifications was best approximated by the level of producing locative nouns and names of agent/doers and /receivers (doers of actions and names of instruments) - there was no correlation between decoding and encoding of formations (apart from names of doers of actions).

Deaf children correctly interpreted $35 \%$ of modification constructions and $20 \%$ mutation constructions. Like hard-of-hearing children, they showed fewest difficulties in interpreting diminutives, paraphrases of which they also produced far more than paraphrases of other formations. Out of mutation categories, they coped best with decoding names of products and objects and names of feature carriers, which suggests analogies with hard-of-hearing children. Deaf children, unlike the hard-of-hearing, had considerable difficulties in decoding feminative constructions.

Deaf children produced on average $10 \%$ of modification constructions and barely $2 \%$ of mutation constructions. 
The presented analyses of the data show that there are certain similarities in the acquisition of word-formation categories by hard-of-hearing and deaf children. In order to present the full picture of the abilities of children with hearing loss in the area of word-formation, quantitative analyses should be supplemented by qualitative ones. It would only be then that we could identify more parallels in the acquisition of word-formation categories by hard-of-hearing and by deaf children. The inclusion of the description of strategies for subjective decoding and encoding word-formation categories in the cases of limited access to the world of sounds would be far beyond the scope of the present study.

\section{References}

Benedict, H. (1979). Early lexical development: Comprehension and production. Journal of Child Language, 6, 183-200.

Chmura-Klekotowa, M. (1971). Neologizmy słowotwórcze w mowie dzieci [Derivational neologisms in the speech of children]. Prace Filologiczne, 21, 99-235.

Clark, E. V. (1980). Lexical innovations: How children learn to create new words. Papers and Reports on Child Language Development, 18, 1-20.

Clark, E. V. (1993). The lexicon in acquisition. Cambridge: Cambridge University Press.

Clark, E.V. \& Berman, R.A. (1984). Structure and use in the acquisition of word formation. Language, 60, 542-590.

Dokulil, M. (1979). Teoria derywacji [Theory of deriving words]. Wrocław: Ossolineum.

Grabias, S. (2007). Język, poznanie, interakcja [Language, cognition, interaction]. In T. Woźniak \& A. Domagała (Eds.), Jęzk. Interakcja. Zaburzenia mowy. Metodologia badań [Language. Interaction. Speech Disorders. Methodology of investigation] (pp. 355-377). Lublin: Wydawnictwo UMCS.

Grabias, S. (1980). O ekspresywności języka. Ekspresja a słowotwórstwo [On expressiveness in Language. Expression and word formation]. Lublin:Wydawnictwo UMCS.

Grabias, S. (1981). Typy derywacji i składnikowa analiza funkcji formantów [Types of derivation and the component analysis of the function of derivational morphemes]. In J. Bartmiński (Ed.), Pojęcie derywacji w lingwistyce [The concept of derivation in linguistics] (pp.127-148). Lublin: Wydawnictwo UMCS.

Grabias, S. (1994). Język w nauczaniu niesłyszących. Zasady programowania systemu komunikacyjnego [Language in teaching the hard-of-hearing/deaf. The rules of programming the communication system]. In S. Grabias (Ed.), Gluchota a język [Deafness and language] (pp.185-221). Lublin: Wydawnictwo UMCS.

Grzegorczykowa, R. (1982). Zarys stowotwórstwa polskiego [An outline of Polish word formation]. Warszawa: PWN. 
Grzegorczykowa, R. \& Puzynina, J. (1984). Słowotwórstwo [Word formation]. In R. Grzegorczykowa, R. Laskowski, \& H. Wróbel (Eds.), Gramatyka wspótczesnego języka polskiego. Morfologia [Grammar of contemporary Polish. Morphology] (pp. 307-512). Warszawa: PWN.

Grzegorczykowa, R. \& Szymanek B. (2001). Kategorie słowotwórcze w perspektywie kognitywnej [Word-formation categories in a cognitive perspective]. In J. Bartmiński (Ed.), Wspótczesny język polski [Contemporary Polish] (pp. 469-484). Lublin: Wydawnictwo UMCS.

Haman, E. (2000a). Semantic vs. formal determinants of derivational morphology development: The case of derived nouns in Polish. Polish Psychological Bulletin, 31 (2), 123-136.

Haman, E. (2000b). Status wyrazów pochodnych w stowniku dziecka - analiza psycholingwistyczna [The status of derived words in the child's lexicon - a psycholinguistic analysis]. Unpublished doctoral dissertation written under the supervision of Professor B. Bokus, Faculty of Psychology, University of Warsaw.

Haman, E. (2003). Early productivity in derivation. A case study of diminutives in the acquisition of Polish. Psychology of Language and Communication, 7 (1), 37-56.

Krakowiak, K. (1995). Fonogesty jako narzędzie formowania języka dzieci z uszkodzonym stuchem [Phonogestures as an instrument of forming the language of children with impaired hearing]. Lublin: Wydawnictwo UMCS.

Krakowiak, K. (2003). Zaburzenia mowy u dzieci z uszkodzeniami słuchu [Speech disorders in children with hearing impairments], In Szkice o wychowaniu dzieci $z$ uszkodzeniami stuchu [Essays on education of children with hearing impairments] (pp. 25-56). Stalowa Wola: Oficyna Wydawnicza Fundacji Uniwersyteckiej KUL.

Kwarciak B. (1995). Początki i podstawowe mechanizmy świadomości metajęzykowej [The beginnings and principal mechanisms of metalinguistic awareness]. Kraków: Wydawnictwo UJ.

Mrozik M. (2003). Wstępne uwagi o morfologii Polskiego Języka Migowego (PJM) [Introductory remarks on the morphology of the Polish Sign Language]. In M. Świdziński \& T. Gałkowski (Eds.), Studia nad kompetencja językowa $i$ komunikacją niestyszacych [Studies on the linguistic competence and communication of the hard-of-hearing/deaf] (pp. 59-77). Warszawa: Wydawnictwa UW. Muzyka E. (2006). Konstrukcje stowotwórcze w świadomości językowej dzieci niestyszacych [Derivational construction in the linguistic awareness of children with hearing loss]. Unpublished doctoral dissertation under the supervision of Professor S. Grabias, Faculty of Humanities UMCS Lublin.

Muzyka E. (2007). Metodologia badań akwizycji regut stowotwórczych. Kwestionariusz dla dzieci niestyszacych [The methodology of investigations of the acquisition of word formation rules]. In T. Woźniak \& A. Domagała (Eds.), 
Język. Interakcja. Zaburzenia mowy. Metodologia badań [Language. Interaction. Speech disorders. Methodology of investigation] (pp. 252-281). Lublin: Wydawnictwo UMCS.

Rakowska, A. (1992). Rozwój systemu gramatycznego u dzieci głuchych [Development of the grammar system in deaf children]. Kraków: Wydawnictwo WSP.

Rozwadowski, J. (1921). O zjawiskach i rozwoju języka. 9. O dwuczłonowości wyrazów [On the henomena and development of language. 9. On two-part composition of words]. Jezzyk Polski, 6, 129-139.

Sambor, J. (2001). Język polski w świetle statystyki [Polish in light of statistics]. In J. Bartmiński (Ed.), Wspótczesny język polski [Contemporary Polish] (pp. 503526). Lublin: Wydawnictwo UMCS.

Skarżyński H., Mueller-Malesińska M., \& Wojnarowska W. (1997). Klasyfikacja zaburzeń słuchu [Classification of Hearing Disorders]. Audiofonologia, 10, 49-66.

Szymanek. B., (1988). Categories and categorization in morphology. Lublin: KUL Press.

Ułaszyn, H. (1915). Słowotwórstwo [Word formation]. In: Encyklopedia polska, vol. 3, part 2, Język polski i jego historya $z$ uwzględnieniem innych języków na ziemiach polskich [Polish and its history taking into consideration other languages on Polish territory] (pp. 1-37). Kraków: Gebethner i S- ka.

Waszakowa, K. (1996). Kategorie słowotwórcze z perspektywy semantyki kognitywnej [Word formation categories in the perspective of cognitive semantics]. In R. Grzegorczykowa \& A. Pajdzińska (Eds.), Jezzkowa kategoryzacja świata [Linguistic categorization of the world] (pp. 285-295). Lublin: Wydawnictwo UMCS. 